\title{
NLRB Primary Jurisdiction and Hot Cargo Issues Arising in Section 301(a) Actions
}

Section 8(e) of the Labor Management Relations Act ${ }^{1}$ ("LMRA") makes it an unfair labor practice for a union and an employer to enter into a hot cargo agreement. ${ }^{2}$ Such an agreement is a form of secondary labor activity by which a union secures the support of a neutral secondary employer in a labor dispute between the union and another, primary employer. Under the agreement, the neutral secondary employer agrees to cease doing business with the primary employer. This loss of business generally increases the economic pressure on the primary employer to accept the union's position in the labor dispute and often burdens the neutral secondary employer by eliminating a traditional market or a low cost source of supply. ${ }^{3}$

There are two possible forums for the resolution of hot cargo issues. The National Labor Relations Board ("NLRB" or "Board") has the power to prevent the enforcement of these agreements. ${ }^{4}$ At the same time, hot cargo disputes are within the scope of the federal courts' jurisdiction over labor-management contracts granted

Labor Management Relations Act, § 8(e), 29 U.S.C. § 158(e) (1976) [hereinafter cited as LMRA]. Section 8(e) was added to the LMRA by the Labor-Management Reporting and Disclosure Act of 1959 ("LMRDA"), Pub. L. No. 86-257, § 704(b), 73 Stat. 519, 543-44. It reads in relevant part:

It shall be an unfair labor practice for any labor organization and any employer to enter into any contract or agreement, express or implied, whereby such employer ceases or refrains from handling, using, selling, transporting, or otherwise dealing in any of the products of any other employer, or to cease doing business with any other person, and any contract or agreement entered into heretofore or hereafter containing such an agreement shall be to such extent unenforcible [sic] and void . . . .

The portion of section $8(\mathrm{e})$ not quoted here creates exceptions for certain agreements in the construction and clothing industries.

2 The term "hot cargo" agreement is derived from the extensive use of these restrictive agreements as an economic pressure tactic by the Teamsters Union in the transportation industry. See H. REP. No. 741, 86th Cong., 1st Sess. 20-23 (1959), reprinted in 1 NLRB, Legislative History of THE Labor-Management Reporting and Disclosure Act of 1959, at 778-81 (1959) [hereinafter cited as LMRDA HistoRy]; S. REP. No. 187, 86th Cong., 1st Sess. 79-80 (1959) (minority report), reprinted in 1 LMRDA HistoRY, supra, at 475-76.

${ }^{3}$ H. REP. No. 741, 86th Cong., 1st Sess. 20-23 (1959), reprinted in 1 LMRDA HiSTORY, supra note 2, at 778-81 (impact of hot cargo agreements on primary employers). See text and note at note 73 infra (impact of secondary boycotts on secondary employers).

- LMRA §§ 10(b), (c), (e), (l), 19 U.S.C. \$§ 160(b), (c), (e), (l) (1976). 
by section 301(a) of the LMRA. ${ }^{5}$ The courts of appeals have taken a variety of approaches in determining what their function is in resolving hot cargo issues in section 301 (a) contract actions. ${ }^{6}$

This comment evaluates these approaches by considering the language and legislative history of section $8(\mathrm{e})$, the rationale for and exceptions to the doctrine of NLRB primary jurisdiction, and the arguments for departing from that doctrine in the special context of section $8(\mathrm{e})$. The comment also considers whether equitable concerns for union pension fund trustees should alter the analysis. It concludes that in most cases, the federal courts should assert jurisdiction and decide hot cargo issues when they arise in section 301(a) suits.

S LMRA § 301(a), 29 U.S.C. § 185(a) (1976). The full text of that section reads:

Suits for violation of contracts between an employer and a labor organization representing employees in an industry affecting commerce as defined in this chapter, or between any such labor organizations, may be brought in any district court of the United States having jurisdiction of the parties, without respect to the amount in controversy or without regard to the citizenship of the parties.

Section 301(a) does not deprive state courts of jurisdiction over breach of contract actions in the labor field, Charles Dowd Box Co. v. Courtney, 368 U.S. 502, 507 (1962), although state courts must apply "principles of federal labor law." Local 174, Int'l Bhd. of Teamsters v. Lucas Flour Co., 369 U.S. 95, 102 (1962).

- See text and notes at notes 13-21 infra. The hot cargo issue in section 301(a) actions implicates two broader concerns. First, the issue reflects the problem of deciding whether the courts should resolve hot cargo disputes in contexts other than section 301 (a) contract enforcement actions. Although the scope of this comment is limited to the section 301(a) context, the other contexts are relevant to the analysis. See text and notes at notes 67-77, 84 infra.

Second, the question reflects the problem of deciding whether the courts should resolve other unfair labor practice issues in section 301(a) enforcement actions. See Meltzer, The Supreme Court, Congress, and State Jurisdiction Over Labor Relations (pt. 2), 59 Colum. L. Rev. 269, 289-301 (1959); Sovern, Section 301 and the Primary Jurisdiction of the NLRB, 76 Harv. L. REv. 529, 559-68 (1963). See, e.g., Local 1898, Int'l Ass'n of Machinists v. Brake \& Elec. Sales Corp., 279 F.2d 590, 592-93 (1st Cir. 1960) (accepting the employer's argument that the union security clause did not apply when the discharge of an employee under the clause would require the employer to commit an unfair labor practice under LMRA § 8(a)(3), 29 U.S.C. § 158(a)(3) (1976)); Southwestern Bell Tel. Co. v. Communications Workers Local 6222, 343 F. Supp. 1165, 1171-72 (S.D. Tex. 1972) (refusing in employer's suit to enforce no-strike clause to consider whether the employer's alleged unfair labor practices justified the union's strike). In several cases courts have refused to force an employer to commit an unfair labor practice under LMRA § 8(a)(1), 29 U.S.C. § 158(a)(1) (1976), when the representational status of the union representing its employees changed between the rendering of an arbitration award favorable to the union and a suit for enforcement of the award. General Warehousemen \& Helpers Local 767 v. Standard Brands, Inc., 579 F.2d 1282, 1291-93 (5th Cir. 1978) (en banc), cert. dismissed, 443 U.S. 913 (1979); Glendale Mfg. Co. v. Local 520, ILGWU, 283 F.2d 936 (4th Cir. 1960), ceri. denied, 366 U.S. 950 (1961). See also Meyers v. Kinney Motors, Inc., 32 A.D.2d 266, 301 N.Y.S.2d 171 (1969) (per curiam). This comment does not propose to provide a complete analysis of every situation encompassed by the broader problem of unfair labor practices in section 301(a) actions. 


\section{BACKGROUND}

Hot cargo issues can arise in three ways in section 301(a) actions. First, an employer may refuse to implement the alleged hot cargo agreement, and the union, ${ }^{7}$ or a pension fund trustee who is a third party beneficiary under the agreement, ${ }^{8}$ sues for breach of contract. The employer then raises the hot cargo issue as a defense, claiming that the agreement is unenforceable and void under section $8(\mathrm{e}) .{ }^{9}$ Second, the employer may seek a declaratory judgment that the agreement is illegal. ${ }^{10}$ Finally, the employer may defend against a union action to enforce an arbitration award by arguing that the award is based on a hot cargo agreement. ${ }^{11}$ The hot cargo issue warrants the same treatment in all three kinds of cases.12

${ }^{7}$ E.g., Pittsburgh Die Sinkers Lodge No. 50 v. Pittsburgh Forgings Co., 255 F. Supp. 142 (W.D. Pa. 1966).

s E.g., Mullins v. Kaiser Steel Corp., 642 F.2d 1302, 1305-08 (D.C. Cir. 1980), cert. granted, 101 S. Ct. 2044 (1981) (No. 80-1345); Waggoner v. R. McGray, Inc., 607 F.2d 1229, 1231 (9th Cir. 1979); Huge v. Long's Hauling Co., 590 F.2d 457, 459 (3d Cir. 1978), cert. denied, 442 U.S. 918 (1979). Only the Mullins court, 642 F.2d at 1311-13, $1318 \mathrm{n} .13$, and one judge in Huge v. Long's Hauling Co., 590 F.2d at 464-65 (Adams, J., concurring), found the plaintiff's status as a pension fund trustee relevant.

In Mullins the trustees also sought to enforce the pension fund obligation under Employee Retirement Income Security Act of 1974 ("ERISA"), § 502(a)(3), 29 U.S.C. \& 1132(a)(3) (1976) (providing pension fund participants, beneficiaries and trustees with a right of action to enforce the provisions of ERISA "or the terms of the plan").

- E.g., Pittsburgh Die Sinkers Lodge No. 50 v. Pittsburgh Forgings Co., 255 F. Supp. 142 (W.D. Pa. 1966).

10 E.g., Todd Shipyards Corp. v. Marine \& Shipbldg. Workers Local 39, 344 F.2d 107 (2d Cir. 1965), aff'g 232 F. Supp. 589 (E.D.N.Y. 1964). If the union seeks a declaratory judgment on the section $8(\mathrm{e})$ issue, the anti-injunction provisions of the Norris-LaGuardia Act, $\S \S 1-15,29$ U.S.C. $\$ \S 101-115$ (1976), may deny the only remedy that is effective before the employer repudiates the agreement. The proper accomodation between section 301 and the Norris-LaGuardia Act is an unsettled area in labor law. Compare Buffalo Forge Co. v. United Steelworkers, 428 U.S. 397, 410-13 (1976) (Norris-LaGuardia Act prohibits injunction to enforce no-strike clause where the strike is the arbitrable grievance) with Boys Markets, Inc. v. Retail Clerks Local 770, 398 U.S. 235, 253-55 (1970) (Norris-LaGuardia Act does not prevent injunction to enforce no-strike clause where strike protests grievance subject to mandatory arbitration).

"I E.g., Orange Belt Dist. Council of Painters No. 48 v. Maloney Specialties, Inc., 639 F.2d 487 (9th Cir. 1980); Botany Indus., Inc. v. New York Joint Bd., Amalgamated Clothing Workers, 375 F. Supp. 485 (S.D.N.Y.), vacated and dismissed as moot sub nom. Robb v. New York Joint Bd., Amalgamated Clothing Workers, 506 F.2d 1246 (2d Cir. 1974).

${ }^{12}$ If the courts can decide section $8(e)$ issues, there is no basis for limiting the form of the employer's remedy. It is clear that declaratory judgment actions are acceptable under section 301. El Paso Bldg. \& Constr. Trades Council v. El Paso Chapter, Associated Gen. Contractors, 376 F.2d 797, 799-800 (5th Cir. 1967); Black-Clawson Co. v. International Ass'n of Machinists Dist. 137, 313 F.2d 179, $181-82$ (2d Cir. 1962). Although the general policy favoring arbitration as a method of resolving labor disputes limits the courts' review of arbitration awards, United Steelworkers v. Enterprise Wheel \& Car Corp., 363 U.S. 593, 597-98 
The courts of appeals have taken contradictory approaches in disposing of hot cargo issues when raised by employers in section 301(a) actions. The Second Circuit has ruled that the NLRB's primary jurisdiction over unfair labor practices ${ }^{13}$ does not prevent a court in a section 301(a) action from declaring a contract clause void and excusing nonperformance when it finds that the clause violates section 8(e). ${ }^{14}$ When NLRB resolution of the claim is pending, the Second Circuit occasionally has stayed section 301(a) proceedings and incorporated the Board's hot cargo ruling into its resolution of the contract claim. ${ }^{15}$ This practice, however, is animated only by a spirit of comity; the Second Circuit asserts that it possesses the power to resolve hot cargo claims. ${ }^{16}$

(1960); United Steelworkers v. Warrior \& Gulf Navigation Co., 363 U.S. 574, 582 (1960); United Steelworkers v. American Mfg. Co., 363 U.S. 564, 568 (1960), arbitration does not legitimize an otherwise illegal contract. Botany Indus., Inc. v. New York Joint Bd., Amalgamated Clothing Workers, 375 F. Supp. 485, 491 (S.D.N.Y.), vacated and dismissed as moot sub nom. Robb v. New York Joint Bd., Amalgamated Clothing Workers, 506 F.2d 1246 (2d Cir. 1974). See also Alexander v. Gardner-Denver Co., 415 U.S. 36, 59-60 (1974) (arbitration award finding no discrimination does not deprive court of jurisdiction in the same dispute under Title VII of the Civil Rights Act of 1964, 42 U.S.C. $\$ 2000 \mathrm{e}-2000 \mathrm{e}-17$ (1976 \& Supp. II 1978)).

${ }^{13}$ For a discussion of the NLRB's primary jurisdiction, see text and notes at notes 42 51 infra.

14 E.g., Todd Shipyards Corp. v. Marine \& Shipbldg. Workers Local 39, 344 F.2d 107, 108-09 (2d Cir. 1965).

${ }^{15}$ See, e.g., National Maritime Union v. Commerce Tankers Corp., 457 F.2d 1127, 1138 (2d Cir. 1972). Once the Board rules, the court incorporates the Board's decision into its final judgment on the contract action. Cf. Barabas v. Prudential Lines, Inc., 451 F. Supp. 765, 769-70 (S.D.N.Y.) (incorporating NLRB Regional Director's opinion into judgment in contract action), aff'd per curiam, 577 F.2d 184 (2d Cir. 1978).

1s Todd Shipyards is still valid in the Second Circuit. See Botany Indus., Inc. v. New York Joint Bd., Amalgamated Clothing Workers, 375 F. Supp. 485, 488-94, vacated and dismissed as moot sub nom. Robb v. New York Joint Bd., Amalgamated Clothing Workers, 506 F.2d 1246 (2d Cir. 1974). See also United Optical Workers Local 408 v. Sterling Optical Co., 500 F.2d 220, 223-24 (2d Cir. 1974) (dictum).

Although not explicitly discussing the issue of primary jurisdiction, the Fifth Circuit implicitly has followed the Second Circuit by permitting courts to decide whether contract clauses violate section 8(e). El Paso Bldg. \& Constr. Trades Council v. El Paso Chapter, Associated Gen. Contractors, 376 F.2d 797, 801 (5th Cir. 1967). Cf. Local 48, Sheet Metal Workers Int'l Ass'n v. Hardy Corp., 332 F.2d 682, 686-87 (5th Cir. 1964) (evaluating whether judicial enforcement of hot cargo clause would constitute an unfair labor practice under LMRA \& 8(b)(4)(ii)(B), 29 U.S.C. \& 158(b)(4)(ii)(B) (1976)). Several other courts have ruled on the validity of hot cargo clauses in section 301 (a) actions without considering the primary jurisdiction problem. See Pittsburgh Die Sinkers Lodge No. 50 v. Pittsburgh Forgings Co., 255 F. Supp. 142, 146 (W.D. Pa. 1966); Coulon v. Carey Cadillac Renting Co., 231 F. Supp. 991 (S.D.N.Y. 1962). Cf. Local 1898, IAM v. Brake \& Elec. Sales Corp., 279 F.2d 590, 592 (1st Cir. 1960) (determining that union's interpretation of union security clause would require the employer to commit an unfair labor practice under section 8(a)(3)). 
The Third ${ }^{17}$ and Ninth $^{18}$ Circuits follow the opposite approach. Deferring to the NLRB's primary jurisdiction, these circuits refuse to consider the merits of a section 8(e) claim when the employer raises it in the context of section 301(a)..$^{10}$ They simply render judgment on the breach of contract claim; the employer can raise the hot cargo issue only by lodging an unfair labor practice charge with the NLRB.

The District of Columbia Circuit recently adopted a third approach. In Mullins v. Kaiser Steel Corp., ${ }^{20}$ the court refused to consider the hot cargo issue when the employer raised it as a defense against a union pension fund trustee suing as a third party beneficiary to the collective bargaining agreement. Grounding its decision on equitable considerations, the court reasoned that union pension fund trustees are entitled to special protection against illegality defenses raised by an employer in a breach of contract action. It implied, however, that its disposition might be different in a case not involving pension fund trustees. ${ }^{21}$

\section{The Congressional Purpose: Dual Remedies For Section 8(e) Violations}

As a general rule, the NLRB has primary jurisdiction to rem-

${ }_{17}$ Huge v. Long's Hauling Co., 590 F.2d 457, 460-61 (3d Cir. 1978), cert. denied, 442 U.S. 918 (1979).

${ }_{18}$ Orange Belt Dist. Council of Painters No. 48 v. Maloney Specialties, Inc, 639 F.2d 487, 491-92 (9th Cir. 1980); Waggoner v. R. McGray, Inc., 607 F.2d 1229, 1234-36 (9th Cir. 1979).

${ }_{18}$ In Waggoner, the Ninth Circuit followed the Third Circuit's decision in Huge by holding that the NLRB's primary jurisdiction requires that a court refrain from determining whether an unfair labor practice has occurred, even when the unfair labor practice involves a contract clause that the court is enforcing under section 301 (a). $607 \mathrm{~F} .2 \mathrm{~d}$ at 1235 . Cf. Heavy Contractor's Ass'n, Inc. v. International Hod Carriers Local 1140, 312 F. Supp. 1345, 1348 (D. Neb. 1969) (addressing the union's argument that a unilateral modification of the contract by the employer would constitute an unfair labor practice under LMRA $\$ 8(d), 29$ U.S.C. $\S 158(\mathrm{~d})$ (1976), and holding that "the determination of whether an unfair labor practice has been committed is not a matter for decision by this Court"), aff'd per curiam, 430 F.2d 1350 (8th Cir. 1970).

${ }^{20} 642$ F.2d 1302, 1313-18 (D.C. Cir. 1980), cert. granted, 101 S. Ct. 2044 (1981) (No. 801345).

21 In reserving the issue the court observed:

Whether a union can obtain specific performance, or even damages for breach, on a contract that is still executory and clearly violative of section $8(\mathrm{e})$ is a different question from whether the trustees of a welfare fund may recover money due on a contract already fully performed on the union side and only arguably violative of section 8(e). Id. at 1318 n.13. See also Huge v. Long's Hauling Co., 590 F.2d 457, 464-65 (3d Cir. 1978) (Adams, J., concurring), cert. denied, 442 U.S. 918 (1979). 
edy unfair labor practices. ${ }^{22}$ Hot cargo claims have priority over most other unfair labor practice charges, and if the NLRB Regional Director "has reasonable cause to believe such [a] charge is true," he can obtain a temporary restraining order from a federal district court. ${ }^{23}$ The NLRB investigates the allegations, and in a meritorious case the Board can seek a permanent court injunction against performance of the agreement. ${ }^{24}$ Several circuits have concluded that by including the hot cargo prohibition with other unfair labor practices in section 8, Congress intended hot cargo issues to be resolved only by the NLRB. ${ }^{25}$ This interpretation, however, ignores the principal impetus for the hot cargo prohibition as well as the language and legislative history of section $8(e)$.

\section{A. Sand Door: The Impetus for the Hot Cargo Prohibition}

As originally enacted, the secondary boycott provisions of section $8(\mathrm{~b})(4)$ of the LMRA $^{28}$ provided that a union could not threaten, coerce, restrain, or strike against any person when the purpose is to pressure a neutral employer to cease doing business with a primary employer. These provisions dealt with coercion of a neutral party; they did not address directly the situation in which the primary employer had agreed to the inclusion of a hot cargo clause in the contract. Nonetheless, in Local 1976, United Brotherhood of Carpenters $v$. NLRB (Sand Door), ${ }^{27}$ the Supreme Court ruled that a union may not use a hot cargo agreement to defend against a section $8(\mathrm{~b})(4)$ proceeding arising from a strike to enforce the agreement. ${ }^{28}$ Although the secondary employer had agreed to cease doing business with the primary employer, the union's strike to enforce the hot cargo clause constituted coercion sufficient to

22 See text and notes at notes $42-49$ infra. The usual remedies available for unfair labor practices are enumerated in section 10 of the LMRA, 29 U.S.C. $\$ 160$ (1976). See generally D. McDowell \& K. Huhn, NLRB Remedies for Unfair labor Practices (1976).

2329 U.S.C. $\$ 160(l)$ (1976).

24 Id. $\$ \S 160(\mathrm{c}),(\mathrm{e})$.

2s "The Congressional scheme for centralized administration of national labor policy would be significantly undermined if courts were permitted to adjudicate unfair labor practice claims independent of the NLRB." Waggoner v. R. McGray, Inc., 607 F.2d 1229, 1235 (9th Cir. 1979). See also Mullins v. Kaiser Steel Corp., 642 F.2d 1302, 1313-18 (D.C. Cir. 1980), cert. granted, 101 S. Ct. 2044 (1981) (No. 80-1345); Huge v. Long's Hauling Co., 590 F.2d 457, 460-61 (3d Cir. 1978), cert. denied, 442 U.S. 918 (1979).

26 Pub. L. No. $80-101, \S 101,61$ Stat. 141 (1947) (current version at 29 U.S.C. $\S 158(b)(4)(i i)(B)$ (1976)).

27357 U.S. 93 (1958).

${ }^{28}$ Id. at 101-08. 
violate section $8(\mathrm{~b})(4) .^{29}$

Sand Door implied, however, that although hot cargo agreements do not provide a defense to unfair labor practice proceedings, they might have other legal effects that would have a subtle influence on secondary employers. ${ }^{30}$ Section $8(\mathrm{e})$, added by the LMRDA, ${ }^{31}$ closed this potential loophole in the secondary boycott prohibition of section $8(\mathrm{~b})(4)$ by making hot cargo agreements themselves generally unenforceable. ${ }^{32}$ In National Woodwork Manufacturers Association v. NLRB, ${ }^{33}$ the Supreme Court recognized that Congress designed section $8(\mathrm{e})$ to protect employers against union actions under section 301 to enforce hot cargo agreements:

Section 8(e) was designed to plug this gap in the legislation by making the "hot cargo" clause itself unlawful. The Sand Door decision was believed by Congress not only to create the possibility of damage actions against employers for breaches of "hot cargo" clauses, but also to create a situation in which such clauses might be employed to exert subtle pressures upon employers to engage in "voluntary" boycotts. ${ }^{34}$

28 Id. at 106-07. Congress later confirmed this interpretation of section 8(b)(4). Pub. L. No. $86-257, \S 704(a), 73$ Stat. 542 (1959) (current version at 29 U.S.C. § 158(b)(4)(ii)(A) (1976)).

so The implication arose from this observation in Justice Frankfurter's opinion for the majority:

Certainly the voluntary observance of a hot cargo provision by an employer does not constitute a violation of $\S 8(\mathrm{~b})(4)(\mathrm{A})$, and its mere execution is not ... prima facie evidence of prohibited inducement of employees. It does not necessarily follow from the fact that the unions cannot invoke the contractual provision in the manner in which they sought to do so in the present cases that it may not, in some totally different context ... still have legal radiations affecting the relations between the parties. Id. at 108.

${ }^{31}$ See note 1 supra.

${ }^{32}$ During consideration of the bill containing section $8(\mathrm{e})$, various committee reports and several congressmen expressed concern about the implications of Sand Door and suggested closing the loophole in the secondary boycott provisions of section $8(\mathrm{~b})(4)$ created by that decision. H.R. REP. No. 741, 86th Cong., 1st Sess. 20-21 (1959), reprinted in 1 LMRDA History, supra note 2, at 778-79; S. REP. No. 187, 86th Cong., 1st Sess. 78-80 (1959), reprinted in 1 LMRDA History, supra note 2, at 474-77; 105 Cong. Rec. $3951-52$ (1959) (remarks of Sen. McClellan), reprinted in 2 LMRDA HISTORY, supra note 2, at 1007; id. at 16590 (remarks of Rep. Thompson), reprinted in 2 LMRDA History, supra note 2, at 1708.

38 3.S. 612 (1967).

34 Id. at 634 (footnote omitted). See also Connell Constr. Co. v. Plumbers \& Steamfitters Local 100, 421 U.S. 616, 628 (1975). In dissent, Justice Stewart observed that "[s]ince $\S 8(\mathrm{e})$ provides that any prohibited agreement is 'unenforcible [sic] and void,' any union effort to invoke legal processes to compel the neutral employer to comply with this purely voluntary agreement would obviously be unavailing." Id. at 650 n.9. 


\section{B. The Language and Legislative History of Section 8(e)}

The express language of section 8(e) not only declares hot cargo clauses to be unfair labor practices, but pronounces them "unenforcible [sic] and void" as well. ${ }^{35}$ Because of the contractual nature of hot cargo clauses, this language must be read in conjunction with section 301(a), which provides that "[s]uits for violation of contracts between an employer and a labor organization ... may be brought in any district court of the United States . . . ."36 If Congress meant for primary jurisdiction to prevail here, the "unenforceable and void" language would be superfluous. ${ }^{37}$ The language adds nothing to the NLRB's enforcement powers: even without it the Board would have the power under section $10(\mathrm{e})$ of the LMRA to thwart union enforcement of hot cargo agreements. ${ }^{38}$ The language only can be properly read as indicating a congressional intent to provide dual forums for remedying section 8(e) violations. ${ }^{39}$

ss See note 1 supra.

so See note 5 supra.

37 The language of the garment industry proviso in section $8(\mathrm{e})$ also undermines the argument that Congress meant for the Board to have primary jurisdiction over these disputes. After excluding certain contracts in the garment industry from the coverage of section 8(e), the proviso goes on to state "[t]hat nothing in this subchapter shall prohibit the enforcement of any agreement which is within the foregoing exception," 29 U.S.C. § 158(e) (1976), implying that section 8(e) prohibits the enforcement of other hot cargo agreements.

${ }^{38}$ Id. $\$ 160(\mathrm{e})$. Under section 10(e), the Board can petition a court of appeals for enforcement of its decisions. It might be argued that Congress intended the "unenforceable and void" language to apply in section 301(a) actions only after the NLRB ruled on the issue of illegality. This view, however, is unreasonable. No union would bring a section 301(a) action to enforce a hot cargo agreement after the NLRB had resolved the issue. After a Board decision, a section 10 (e) enforcement order would prevent the section 301(a) action even without the section 8(e) language.

30 As originally introduced in the Senate, the bill containing section 8(e) did not prohibit hot cargo agreements. See S. 1555, 86th Cong., 1st Sess. (1959), reprinted in 1 LMRDA HISTORY, supra note 2, at 338. Senator Gore proposed an amendment to prohibit hot cargo agreements in the trucking industry, but did not include the "unenforceable and void" language. 105 CoNG. REc. 6556 (1959), reprinted in 2 LMRDA HISTORY, supra note 2, at 1161-62. Senator Smathers later proposed the addition of this language to Senator Gore's hot cargo prohibition and stated that his amendment would reach contracts already in force. 105 Cong. REc. 6730 (1959), reprinted in 2 LMRDA HISTORY, supra note 2, at 1242. At least one court has interpreted this legislative history to mean that the unenforceable and void language was added to section 8(e) only to reach contracts in force at the time of its adoption. Mullins v. Kaiser Steel Corp., 466 F. Supp. 911 , 916 (D.D.C. 1979), aff'd, 642 F.2d 1302 (D.C. Cir. 1980), cert. granted, 101 S. Ct. 2044 (1981) (No. 80-1345). This result cannot have been the only purpose of the amendment, however, because it does not explain why the language voids hot cargo agreements entered into "hereafter." See id., 642 F.2d at 1333 (Wilkey, J., dissenting) ("I believe that Congress meant what it said, and that these clauses are unenforceable by the federal Courts."). A House amendment to the Senate bill extended 
The legislative history reinforces this interpretation. Numerous congressmen emphasized that section 8(e) made hot cargo agreements both unfair labor practices and unenforceable and void..$^{40}$ Senator Goldwater explained the consequences of the additional language by observing that under section $8(\mathrm{e})$, the breach of a hot cargo agreement "does not constitute a good cause of action in a suit at law to recover damages for the breach or to secure specific performance of the agreement."11

\section{NLRB Primary JuRisdiction and Its Exceptions}

In addition to the language and legislative history of section 8(e), a careful analysis of the contours of the NLRB's primary jurisdiction indicates that courts should not be divested of jurisdiction over hot cargo issues in section 301(a) actions.

The theory of NLRB primary jurisdiction is deceptively straightforward. Sections 7 and 8 of the LMRA respectively enumerate protected and prohibited activities in the labor field. ${ }^{42}$ Section 8 enumerates unfair labor practices, over which Congress gave the NLRB jurisdiction.48 In Garner v. Teamsters Local 776, ${ }^{44}$ the Supreme Court observed that Congress's main purpose in establishing the NLRB was to create an agency having special famil-

the hot cargo prohibition to all labor-management contracts, except for certain contracts in the garment and construction industries. See H.R. CoNr. REP. No. 1147, 86th Cong., 1st Sess. 39 (1959), reprinted in I LMRDA HISTORY, supra note 2, at 943.

40105 CoNG. REc. 7022 (1959) (remarks of Sen. Kennedy), reprinted in 2 LMRDA HisTORY, supra note 2, at 1258; id. at 10104, 17904 (remarks of Sen. Goldwater), reprinted in 2 LMRDA HistoRy, supra note 2, at 1290, 1437; id. at 14347-48 (remarks of Rep. Griffin), reprinted in 2 LMRDA HistoRY, supra note 2, at 1523; id. at 15545 (remarks of Rep. Rhodes), reprinted in 2 LMRDA HisTORY, supra note 2, at 1581. See also H.R. Conf. REP. No. 1147, 86th Cong., 1st Sess. 39 (1959), reprinted in 1 LMRDA HISTORY, supra note 2, at 943.

105 Cong. REc. A8523 (1959), reprinted in 2 LMRDA HistoRy, supra note 2, at 1857. Cf. 105 CoNG. REc. 17900 (1959) (remarks of Sen. Kennedy), reprinted in 2 LMRDA HistoRY, supra note 2, at 1433 (section 8(e) is not intended "to change the law with respect to the judicial enforcement of [contracts covered by the construction industry proviso]," implying that judicial enforcement of other contracts is affected).

Because hot cargo agreements are generally unenforceable, pension fund agreements that violate section $8(\mathrm{e})$ are unenforceable whether the obligation to honor the agreement arises from LMRA § 301(a), 29 U.S.C. § 185(a) (1976); ERISA § 502(a)(3), 29 U.S.C. $\S 1132(\mathrm{a})(3)$ (1976); or Multiemployer Pension Plan Amendments Act of 1980, § 306(a), 29 U.S.C.A. \& 1145 (1981 Supp.) (statutory obligation to honor multiemployer pension fund agreements).

1229 U.S.C. $\$ \S 157,158(1976)$.

43 Id. § 158; LMRA § 10(a), 29 U.S.C. § 160(a) (1976) (granting NLRB jurisdiction over unfair labor practices defined in section 8 ).

4446 U.S. 485 (1953). 
iarity with the complex factual problems arising in the field of labor relations. ${ }^{45}$ According to the Court, only an agency with administrative expertise in the field could apply the LMRA with the consistency that Congress desired; concurrent forums for remedying unfair labor practices might undermine uniform interpretation of the Act or provide inconsistent remedies. ${ }^{46}$

Although Garner dealt with a conflict between state courts and the NLRB, ${ }^{47}$ the policy of deferring to administrative expertise also divests federal forums of jurisdiction over some unfair labor practice issues. In San Diego Building Trades Council v. Garmon, 48 the Supreme Court devised an appealingly simple formula for invoking primary jurisdiction: "[w]hen an activity is arguably subject to $\S 7$ or $\S 8$ of the Act, the States as well as the federal courts must defer to the exclusive competence of the $\mathrm{Na}$ tional Labor Relations Board . . . ."49

The Supreme Court has developed numerous exceptions to the Garmon formula. ${ }^{50}$ These exceptions do not diminish the impor-

4s Id. at 490 .

16 Id. at $488-91,501$. The policy favoring administrative expertise arises from general principles of administrative law:

[I]n cases raising issues of fact not within the conventional experience of judges or cases requiring the exercise of administrative discretion, agencies created by Congress for regulating the subject matter should not be passed over. This is so even though the facts after they have been appraised by specialized competence serve as a premise for legal consequences to be judicially defined. Uniformity and consistency in the regulation of business entrusted to a particular agency are secured, and the limited functions of review by the judiciary are more rationally exercised, by preliminary resort for ascertaining and interpreting the circumstances underlying legal issues to agencies that are better equipped than courts by specialization, by insight gained through experience, and by more flexible procedure.

Far East Conference v. United States, 342 U.S. 570, 574-75 (1952).

47346 U.S. at 490-91. In Hill v. Florida, 325 U.S. 538, 543-44 (1945), the Supreme Court declared for the first time that state statutes that interfere with the policies of federal labor legislation are void. In Garner, the Court went further by ruling that the states could not provide alternative remedies for the unfair labor practices enumerated in section 8 of the LMRA. 346 U.S. at 490-91. See also Meltzer (pt. 1), supra note 6, at 6, 15-17.

48359 U.S. 236 (1959).

10 Id. at 245. Garmon held that the assumption of jurisdiction by a state court over the labor dispute at issue was improper. Id. at 246.

so The Garmon rule does not preempt state court jurisdiction in cases involving conduct "so deeply rooted in local feeling and responsibility that . . . [the Supreme Court] could not infer that Congress . . . deprived the States of the power to act." Id. at 244. See, e.g., UAW v. Russell, 356 U.S. 634 (1958) (union violence). Other exceptions to Garmon are discussed in the remainder of this part. For general discussion of NLRB primary jurisdiction and its exceptions, see Cox, Labor Law Preemption Revisited, 85 Harv. L. REv. 1337 (1972); Lesnick, Preemption Reconsidered: The Apparent Reaffirmation of Garmon, 72 Colum. L. Rev. 469 (1972). 
tance of the policies underlying primary jurisdiction; rather, they indicate that under some circumstances, a competing policy or a special expertise of the federal courts justifies the potential interference with uniform application of the LMRA. ${ }^{31}$ This part considers these exceptions to decide whether hot cargo cases brought under section 301 (a) are sufficiently analogous to justify exempting them as well from the NLRB's primary jurisdiction.

\section{A. The Section 301(a) Exception}

Congress enacted section 301(a) in the Labor Management Relations Act of $1947 .{ }^{52}$ In Textile Workers Union v. Lincoln Mills, ${ }^{53}$ the Supreme Court interpreted section 301(a) to reflect a firm congressional policy that a judicial forum could provide a more prompt and effective remedy for breach of contract than could the processes of the Board. ${ }^{54}$ Writing for the majority, Justice Douglas

s1 See Vaca v. Sipes, 386 U.S. 171, 180 (1967) ("[T]he decision to preempt federal and state court jurisdiction over a given class of cases must depend upon the nature of the particular interests being asserted and the effect upon the administration of national labor policies of concurrent judicial and administrative remedies."). See also Amalgamated Ass'n of St. Employees v. Lockridge, 403 U.S. 274, 318 (1971) (White, J., dissenting).

s2 Pub. L. No. 80-101, §301(a), 61 Stat. 136, 156 (1947) (codified at 29 U.S.C. $§ 185(a)$ (1976)). See note 5 supra.

${ }^{\text {s3 }} 353$ U.S. 448 (1957).

${ }^{\text {st }}$ Id. at 451-55. The principal evidence for the Court's position was a statement in the conference report:

The Senate amendment contained a provision which does not appear in section 8 of existing law. This provision would have made it an unfair labor practice to violate the terms of a collective bargaining agreement or an agreement to submit a labor dispute to arbitration. The Conference Agreement omits this provision of the Senate amendment. Once parties have made a collective bargaining contract the enforcement of that contract should be left to the usual processes of the law and not to the $\mathrm{Na}$ tional Labor Relations Board.

H.R. Conf. Rep. No. 510, 80th Cong., 1st Sess. 41-42 (1947), reprinted in 1 NLRB, LegisLAtive History of the Labor Management Relations Act, 1947, at 545-46 (1948) (emphasis added) [hereinafter cited as LMRA HISTORY]. Congress's principal purpose in extending federal jurisdiction to cover labor-management agreements was to avoid the procedural diffculties of suing unincorporated unions for breach of contract. S. REP. No. 105, 80th Cong., 1st Sess. 16-18 (1947), reprinted in 1 LMRA History, supra, at 422-24; 93 Cong. Rec. 3839 (1947) (remarks of Sen. Taft), reprinted in 2 LMRA History, supra, at 1014. Under the Senate bill, both the NLRB and the federal courts would have had jurisdiction to enforce collective bargaining agreements. S. 1126, 80th Cong., 1st Sess. §§ 8(a)(6), (b)(5) (1947), reprinted in 1 LMRA HISTORY, supra, at 111, 114. Several members of the conference committee objected to NLRB jurisdiction over breach of contract actions. See, e.g., 93 Cong. REc. 6443 (1947) (remarks of Sen. Taft), reprinted in 2 LMRA HisToRY, supra, at 1539. See also S. REP. No. 105, 80th Cong., 1st Sess. (pt. 2) 13 (1947) (minority report), reprinted in 2 LMRA HisToRY, supra, at 475. The conference committee consequently eliminated Board jurisdiction over labor-management agreements, leaving only the right of action in the fed- 
noted that section 301(a) "does more than confer jurisdiction in the federal courts over labor organizations. It expresses a federal policy that federal courts should enforce these agreements on behalf of or against labor organizations and that industrial peace can be best obtained only in that way." 301(a) granted the federal courts substantive powers to fashion a body of federal law to promote the prompt and effective enforcement of labor-management contracts. ${ }^{56}$

Once the judicial forum for contractual enforcement had been established, the Court began to delineate the manner in which judicial and Board remedies were to be integrated. In Smith v. Evening News Association, ${ }^{57}$ the Court made clear that the NLRB's primary jurisdiction does not require the dismissal of a section 301(a) action simply because the breach of contract also involves activity prohibited under section 8 of the LMRA. ${ }^{88}$ The contract in that case prohibited discrimination between union and nonunion employees. The employer violated the contract by locking out a union employee while permitting nonunion executive staff to continue working. Because the discrimination arguably was an unfair labor practice under section $8(a)(3),{ }^{60}$ the Michigan courts applied the Garmon rule and dismissed the employee's claim. ${ }^{60}$ In revers-

eral courts under section 301(a).

ss 353 U.S. at 455 (1957).

s6 Id. at 456-58. Justice Douglas enumerated the possible sources of the new federal law:

The Labor Management Relations Act expressly furnishes some substantive law. It points out what the parties may or may not do in certain situations. Other problems will lie in the penumbra of express statutory mandates. Some will lack express statutory sanction but will be solved by looking at the policy of the legislation and fashioning a remedy that will effectuate that policy. The range of judicial inventiveness will be determined by the nature of the problem.

Id. at 457.

371 U.S. 195 (1962).

sB Id. at 195-98. Smith relied on two earlier cases that had dismissed summarily the contention that the NLRB's primary jurisdiction extended to a section 301(a) action when the breach of contract involved arguably protected strike activity. See Atkinson v. Sinclair Refining Co., 370 U.S. 238, 245 n.5 (1962); Local 174, International Bhd. of Teamsters v. Lucas Flour Co., 369 U.S. 95, 101 n.9 (1962) ("Since this was a suit for violation of a collective bargaining contract within the purview of $\S 301(\mathrm{a})$ of the Labor Management Relations Act of 1947, the pre-emptive doctrine of cases such as [Garmon], based upon the exclusive jurisdiction of the National Labor Relations Board, is not relevant."). Smith was reaffirmed and extended to suits for an injunction in William E. Arnold Co. v. Carpenters Dist. Council, 417 U.S. 12, 16-20 (1974).

s9 29 U.S.C. $\S 158(a)(3)$ (1976).

0 See Smith v. Evening News Ass'n, 362 Mich. 350, 365, 106 N.W.2d 785, 786 (1961), rev'd, 371 U.S. 195 (1962). 
ing, the Supreme Court held that "[ $[t]$ he authority of the Board to deal with an unfair labor practice which also violates a collective bargaining contract is not displaced by $\S 301$, but it is not exclusive and does not destroy the jurisdiction of the courts in suits under § $301 .{ }^{\prime \prime}$

In asserting jurisdiction over hot cargo issues, the Second Circuit has interpreted Smith as creating a broad exception to the NLRB's primary jurisdiction for all unfair labor practices arising in section 301(a) actions. ${ }^{62}$ The reasoning of Smith, however, is not fully applicable to hot cargo controversies. In cases like Smith, the party seeking judicial relief is squarely within the policies of section 301(a) because it requests the prompt enforcement of the contract's terms. ${ }^{63}$ The court simply is asked to enforce the parties' private bargain. ${ }^{64}$ In hot cargo disputes, only the union seeks enforcement of the agreement. The employer, seeking to avoid the Board's primary jurisdiction, asks the court to sanction the violation of the contract's terms; it asks the court to apply not the terms of the contract, but the terms of section $8(e) .^{68}$ The analogy

61 371 U.S. at 197.

82 "The Supreme Court has all but sounded the death-knell of the theory of exclusive NLRB jurisdiction in cases arising under section 301 of the Labor-Management Relations Act." Carey v. General Elec. Co., 315 F.2d 499, 508 (2d Cir. 1963). One could interpret illphrased dicta from other Supreme Court opinions as supporting the Second Circuit's view. See, e.g., Vaca v. Sipes, 386 U.S. 171, 184 (1967); Atkinson v. Sinclair Ref. Co., 370 U.S. 238, 245 n.5 (1962); Local 174, Int'l Bhd. of Teamsters v. Lucas Flour Co., 369 U.S. 95, 101 n.9 (1962). The implications of these cases actually are narrower than their language might indicate. See text and notes at notes 63-65 infra.

${ }^{63}$ Cf. Vaca v. Sipes, 386 U.S. 171, 183-88 (1967) (court has jurisdiction over fair representation issues in part because such issues frequently are conditions precedent to an employee's section 301.(a) contract enforcement action against the employer).

${ }^{64}$ In addition to the contract enforcement policy of section 301 (a), cases like Smith also engage the federal labor policy of promoting grievance settlement procedures chosen by parties to collective bargaining agreements. William E. Arnold Co. v. Carpenters Dist. Council, 417 U.S. 12, 16-17 (1974). See also Collyer Insulated Wire, 192 N.L.R.B. 837, 843 (1971) (when dispute is arbitrable, Board exercises discretion to defer unfair labor practice proceedings pending arbitration because it is "consistent with the fundamental objectives of Federal law to require the parties here to honor their contractual obligations rather than, by casting this dispute in statutory terms, to ignore their agreed-upon procedures"); 29 U.S.C. $\S 173(d)(1976)$ (settlement of contract disputes by "a method agreed upon by the parties" is more desirable than government conciliation and mediation). The same policy permits arbitration in cases normally reserved for the NLRB. See Carey v. Westinghouse Elec. Corp., 375 U.S. 261, 263-66 (1964) (court may order arbitration even when dispute concerns work assignments usually decided by the NLRB). This policy favoring private resolution obviously is not applicable in the section 301 (a) hot cargo case.

os See Waggoner v. R. McGray, Inc., 607 F.2d 1229 (9th Cir. 1979). Relying on Amalgamated Ass'n of St. Employees v. Lockridge, 403 U.S. 274, 300-01 (1971), Waggoner argued that "the primary jurisdiction principle is displaced in section 301 actions only to the extent 
to Smith, therefore, is imperfect. ${ }^{66}$

\section{B. The Section 303 Exception}

Under section 303 of the LMRA, ${ }^{67}$ anyone injured by a strike or coercion consituting an unfair labor practice under section $8(\mathrm{~b})(4)^{68}$ may bring suit in federal court for compensatory damages. In International Longshoremen's \& Warehousemen's Union $v$. Juneau Spruce Corp., ${ }^{69}$ the Supreme Court rejected the claim that the Board had primary jurisdiction over section $8(\mathrm{~b})(4)$ issues in such suits, concluding that Congress intended to create independent remedies before the courts and the Board..$^{70}$ As a result, federal courts in section 303 actions may decide for themselves whether unfair labor practices under section $8(b)(4)$ have been committed.

Some section 303 damage actions inevitably involve hot cargo

that the section 301 action is governed by the terms of the collective bargaining agreement." $607 \mathrm{~F} .2 \mathrm{~d}$ at 1235 (emphasis added).

" Another exception to the NLRB's primary jurisdiction, sometimes cited in support of judicial resolution of hot cargo issues, also is not squarely on point. When unfair labor practice issues arise in antitrust actions, the courts do not defer to the NLRB's primary jurisdiction. See Connell Constr. Co. v. Plumbers \& Steamfitters Local 100, 421 U.S. 616, 626 (1975) ("the federal courts may decide labor law questions that emerge as collateral issues in suits brought under independent federal remedies, including the antitrust laws"); Local 189, Amalgamated Meat Cutters v. Jewel Tea Co., 381 U.S. 676, 684-88 (1965) (opinion of White, J.) (same); id. at $710 \mathrm{n.18}$ (Goldberg, J., concurring in the result) (same). The Connell exception represents a balance between the policies of antitrust enforcement and the policies of NLRB primary jurisdiction and thus is not directly applicable in the section 301(a) hot cargo context. See Mullins v. Kaiser Steel Corp., 642 F.2d 1302, 1317 (D.C. Cir. 1980), cert. granted, 101 S. Ct. 2044 (1981) (No. 80-1345); Waggoner v. R. McGray, Inc., 607 F.2d 1229, 1236 n.9 (9th Cir. 1979); Huge v. Long's Hauling Co., 590 F.2d 457, 460-61 (3d Cir. 1978), cert. denied, 442 U.S. 918 (1979). However, the Connell exception illustrates the reasoning process used by the Supreme Court in making exceptions to the NLRB's primary jurisdiction. Under this balancing approach, the importance of limiting secondary boycott activities by labor unions would seem to justify a similar exception for hot cargo issues. See text and notes at notes 67-77 supra.

${ }^{87} 69$ U.S.C. $\$ 187$ (1976). The section provides in part:

(a) It shall be unlawful, for the purpose of this section only, in an industry or activity affecting commerce, for any labor organization to engage in any activity or conduct defined as an unfair labor practice in section 158(b)(4) of this title.

(b) Whoever shall be injured in his business or property by reason [of] any violation of subsection (a) of this section may sue therefor in any district court of the United States . . . and shall recover the damages by him sustained and the cost of the suit.

68 29 U.S.C. § 158(b)(4) (1976).

60 342 U.S. 237 (1952).

${ }^{70}$ Id. at 243-45. See also Local 20, Teamsters Union v. Morton, 377 U.S. 252, 258 n.13 (1964). 
issues, ${ }^{71}$ and concurrent jurisdiction creates the possibility of conflicting decisions emanating from different forums in the same case. ${ }^{72}$ Congress, however, expressly provided in section 303 that the courts serve as an alternative forum for remedying section $8(b)(4)$ unfair labor practices, concluding that the secondary boycotts prohibited by section $8(\mathrm{~b})(4)$ are so dangerous to weak neutral employers that the victims of such practices require a prompt and complete remedy against the boycotting union. ${ }^{73}$

${ }^{71}$ Section $8(b)(4)$ makes it an unfair labor practice for a union to strike against or threaten and coerce any employer when the object is, among other things, to force the employer to enter into an illegal hot cargo agreement. 29 U.S.C. § 158(b)(4)(ii)(A) (1976). The section also makes it an unfair labor practice for a union to strike against or threaten and coerce an employer to enforce an illegal hot cargo agreement. Id. § 158(b)(4)(ii)(B). When unfair labor practices defined by sections $8(\mathrm{~b})(4)(\mathrm{ii})(\mathrm{A})$ or $(\mathrm{B})$ underlie a section 303 damage action, the court must determine whether the agreement that the union sought or enforced was an illegal hot cargo agreement. See, e.g., Feather v. UMW Dist. 2, 470 F. Supp. 606, 60709 (W.D. Pa. 1979); Frito-Lay, Inc. v. Retail Clerks Local 7, 452 F. Supp. 1381, 1385-86 (D. Colo. 1978); Ackerman-Chillingworth v. Pacific Elec. Contractors Ass'n, 405 F. Supp. 99, 114-18 (D. Hawaii 1975), aff'd as to antitrust defense, 579 F.2d 484 (9th Cir. 1978), cert. denied, 439 U.S. 1089 (1979).

72 In United Brick \& Clay Workers v. Deena Artware, Inc., 198 F.2d 637 (6th Cir.), cert. denied, 344 U.S. 897 (1952), a case not involving hot cargo issues, the court and the Board reached inconsistent results. Compare id. (deciding in a section 303 action that strike violated section 8(b)(4)) with NLRB v. Deena Artware, Inc., 198 F.2d 645 (6th Cir. 1952) (NLRB decision in section $8(b)(4)$ proceeding that strike did not violate that section; enforcement granted), cert. denied, 345 U.S. 906 (1953). The Sixth Circuit rationalized the inconsistency thus:

We recognize that this finding is contrary to the finding in the companion case of N.L.R.B. v. Deena Artware, Inc. . . . . Under our existing system of courts, juries, administrative agencies, and appellate review, such findings, even though inconsistent, are not invalid . . . . The two proceedings, even though arising out of the same labor dispute, were heard by separate fact finding agencies. . . . Necessarily, the evidence produced in the different proceedings . . . was not identical. Each fact finding agency was entitled to make its own decision upon the evidence before it.

198 F.2d at 642.

${ }^{33}$ During the consideration of the Taft-Hartley amendments to the National Labor Relations Act in 1947, a principal concern of Congress was the inadequacy of Board remedies for small neutral employers who became embroiled in a labor dispute because of a union's secondary boycott activities. Senators who proposed the amendment adding the section 303 damage action to the bill did so to provide prompt and complete relief for these neutral employers:

To a small storekeeper, or machine shop [sic], picketed out of business by unions intervening between him and his employees, or to the farmer prevented from unloading his perishable produce, the remedy of dealing with the NLRB is a weak reed. There will only be a satisfactory remedy if he can go to his local court and obtain an injunction, first temporary and then permanent, against interference of this kind.

In the field of labor relations the large companies can generally look after themselves, but the power of the labor unions is being used indiscriminately against the small businessman, and he is quickly forced to capitulate by danger of bankruptcy.

The amendment proposes that he be entitled to file a suit for damages.... 
The hot cargo exception to the NLRB's primary jurisdiction in section 303 cases provides support for a similar exception for hot cargo actions brought under section 301(a). The secondary boycott provisions of section $8(\mathrm{~b})(4)$ protect neutral employers against union coercion when the purpose of the coercion is to obtain or to enforce a hot cargo agreement. ${ }^{24}$ The hot cargo prohibition in section 8(e) protects neutral employers against the adverse economic impact of the hot cargo agreement itself. ${ }^{75}$ If a damage remedy for secondary boycotts is available in the courts under section 303 , it is anomalous to deny a judicial remedy for section $8(\mathrm{e})$ violations under section 301(a)..$^{76}$ Without such a remedy, neutral employers who are strong enough to resist a union's demands for hot cargo agreements and who thereby provoke the union to strike would have a remedy under section 303 , while neutral employers who are too weak to withstand a strike would be forced to accede to the union's demands for a hot cargo agreement and suffer without a judicial remedy.

Moreover, if courts are competent to decide hot cargo issues in section 303 suits, they surely are competent to decide them in section 301 (a) suits. If the policies underlying the secondary boycott prohibitions in section $8(b)(4)$ are sufficient to outweigh the benefits of the NLRB's primary jurisdiction, those same policies are sufficient within the context of section $8(e) .^{77}$

S. Rep. No. 105, 80th Cong., 1st Sess. 54 (1947) (supplementary views of Sen. Taft), reprinted in 1 LMRA Hrstory, supra note 54, at 460. See also 93 Cong. REc. 4836, 4838 (1947) (remarks of Sen. Ball), reprinted in 2 LMRA HISTORY, supra note 54, at 1351, 1355. The Senate accepted Senator Taft's amendment, 93 CoNG. REc. 4874 (1947), reprinted in 2 LMRA HisToRY, supra note 54, at 1400, and the conference committee retained section 303 in the final version of the LMRA, H.R. CoNr. REP. No. 510, 80th Cong., 1st Sess. 67 (1947), reprinted in 1 LMRA HisTORY, supra note 54 , at 571.

74 29 U.S.C. $\S \S 158(\mathrm{~b})(4)(\mathrm{ii})(\mathrm{A}),(\mathrm{B})(1976)$.

75 Hot cargo agreements frequently will raise the neutral employer's costs by preventing it from doing business with a low cost supplier or a traditional purchaser. For some employers, however, the costs of potential strikes or other disruptions of production may exceed the casts of the hot cargo agreement. In that case, the employer cannot vigorously oppose the union's proposal for a hot cargo agreement.

76 But see Mullins v. Kaiser Steel Corp., 642 F.2d 1302, 1314 (D.C. Cir. 1980) ("When Congress has spoken so directly on the remedies to be provided for statutory violations, it is not for the courts to add remedies of their own."), cert. granted, 101 S. Ct. 2044 (1981) (No. 80-1345).

${ }^{77}$ An interpretation of sections $8(e)$ and $301(a)$ that permits a judicial remedy under section 301(a) for the violation of section 8(e) is consistent with the LMRA's system of employer remedies for serious union unfair labor practices. Although the section 303 damage remedy does not apply to sections $8(\mathrm{e})$ and $8(\mathrm{~b})(7), 29$ U.S.C. $\$ 158(\mathrm{~b})(7)(1976)$, the section $10(l)$ expedited Board remedy, 29 U.S.C. $\$ 160(l)(1976)$, does cover them, along with sec- 


\section{The Fair Representation Exception}

The union's duty of fair representation toward its members was developed by federal courts that implied a cause of action from the LMRA's exclusive representation provisions. ${ }^{78}$ In $\mathrm{Mi}$ randa Fuel Co., ${ }^{78}$ however, the NLRB also assumed jurisdiction over fair representation claims by ruling that a union's breach of its duty of fair representation constitutes an unfair labor practice. ${ }^{80}$ The problem of deference to the Board's primary jurisdiction in this context was addressed by the Supreme Court in Vaca $v$. Sipes. ${ }^{81}$ The Court held that the federal courts may retain jurisdiction over fair representation disputes despite the Board's ruling that such actions are unfair labor practices. ${ }^{82}$ The Court justified concurrent jurisdiction in part by arguing that although administrative expertise is desirable in fair representation cases, the courts developed the concept and therefore have as much experience in the area as the Board. ${ }^{83}$ This considerable expertise with fair rep-

tions 8(b)(4)(ii)(A), (B), and (C), 29 U.S.C. $\$ \S 158(b)(4)(i i)(A),(B),(C)$ (1976). All three unfair labor practices involve serious union pressures and require a prompt remedy for the employer. Although this justifies expedited Board review under section $10(l)$, it also justifies additional remedies, individually tailored for each unfair labor practice.

In secondary boycott cases under section 8(b)(4), the union's coercive activity is the cause of the employer's damages. Because federal labor law disfavors court ordered antiunion injunctions, see Buffalo Forge Co. v. United Steelworkers, 428 U.S. 397, 405-12 (1976); Norris-LaGuardia Act, $\S \S 1-15,29$ U.S.C. $\$ \S 101-115$ (1976), a damage remedy is provided under section 303 as an alternative to the section $10(l)$ procedure. 29 U.S.C. $\$ 187$ (1976). In organizational picketing cases under section 8(b)(7)(C), 29 U.S.C. $\$ 158(b)(7)(C)(1976)$, the unresolved representational issue is the principal source of the employer's damages, and assuming that the procedural requirements are met, the most appropriate remedy is an expedited Board election, id. In section $8(\mathrm{e})$ cases, the hot cargo agreement is the principal source of the employer's damages, and the most appropriate alternative remedy is to apply the "unenforceable and void" language. This analysis suggests that there also should be an alternative judicial remedy for the violation of sections $8(\mathrm{~b})(7)(\mathrm{A})$ and (B), but Congress would have to amend section 303 to provide for a damages remedy.

${ }^{78}$ Cf. Steele v. Louisville \& N.R.R., 323 U.S. 192 (1944) (duty of fair representation arising from exclusive representation provisions of the Railway Labor Act). Syres v. Oilworkers Local 23, 350 U.S. 892 (1955) (per curiam), has been interpreted as extending the duty of fair representation to the LMRA. R. GoRMAN, BASIC TEXT ON LABOR LAw UNIONIZATION AND COLLECTIVE BARgaining $\$ 30-1$, at 697-98 (1976). The duty of fair representation is an equitable principle analogous to a fiduciary duty; it arises whenever the union exclusively represents a group of employees, even if there is no statutory basis for the duty, e.g., Lerma v. D'Arrigo Bros. Co., 77 Cal. App. 3d 836, 842, 144 Cal. Rptr. 18, 22 (1978).

79140 N.L.R.B. 181 (1962), enforcement denied, 326 F.2d 172 (2d Cir. 1963).

${ }^{80} \mathrm{Id}$. at 185 . The Board ruled that the duty of fair representation arose from section 7 and that its breach violated section $8(\mathrm{~b})(1)(\mathrm{A})$.

81386 U.S. 171 (1967).

82 Id. at 183 .

ss Id. at 180-82. The Court also noted that the procedures of the Board, geared princi- 
resentation issues diminishes, although it does not eliminate, the danger of conflicting adjudications.

Federal courts have comparable experience with hot cargo issues because of their frequent occurrence in antitrust litigation ${ }^{84}$ and in section 303 damage actions. ${ }^{85}$ There is thus no reason for denying the courts jurisdiction over the same issues in section 301(a) actions.

\section{Equitable Considerations}

In Mullins v. Kaiser Steel Corp., ${ }^{86}$ the District of Columbia Circuit injected equitable considerations into its evaluation of whether courts should decide hot cargo issues. In that case, a union pension fund trustee sued as a third party beneficiary for enforcement of the collective bargaining agreement. Refusing to consider the employer's hot cargo defense, the court argued that only the union, and not the innocent pension fund trustees, was responsible for the illegal agreement. ${ }^{87}$ Because the union might have given

pally to protection of the public interest, might frustrate the primary purpose of fair representation by preventing remedies in individual cases. Id. at 182-83.

s4 See, e.g., Connell Constr. Co. v. Plumbers \& Steamfitters Local 100, 421 U.S. 616, 626-33 (1975). The Third Circuit has argued that the nonstatutory exemption from the antitrust laws for labor-related activity does not extend to activity that forseeably violates section 8(e). Consolidated Express, Inc. v. New York Shipping Ass'n, Inc. (Conex), 602 F.2d 494, 512-22 (3d Cir. 1979), vacated and remanded on other grounds, 448 U.S. 902 (1980). In Conex the NLRB already had ruled that the agreement violated section 8(e). International Longshoremen's Ass'n, 221 N.L.R.B. 956, 961 (1975), enforced, 537 F.2d 706 (2d Cir. 1976), cert. denied, 429 U.S. 1041 (1977). In similiar situations, however, the courts presumably may resolve hot cargo issues as well, because they are collateral labor law issues arising in an antitrust action. See note 66 supra.

ss See note 71 supra.

${ }^{88} 642$ F.2d 1302, 1311-13, 1318 n.13 (D.C. Cir. 1980), cert. granted, 101 S. Ct. 2044 (1981) (No. 80-1345).

87 The court stated:

As a rule, third-party beneficiaries, like the Trustees here, are subject to the contract defenses of nonperforming promisors. But the Trustees of a union welfare fund are sometimes immune from contract defenses that could be asserted against the union itself because such a rule better serves the concern of federal labor policy to protect union members and their families from the actionable wrongs of their union representatives. . . . We see no reason for not applying that exemption here.

Id. at 1312. See also Huge v. Long's Hauling Co., 590 F.2d 457, 464-65 (3d Cir. 1978) (Adams, J., concurring) ("Ensuring the viability of these funds and protecting the employees' investment from dissipation as a result of union or employer conduct or misconduct has for many years been a concern of the federal government."), cert. denied, 442 U.S. 918 (1979).

These courts principally relied on Lewis v. Benedict Coal Corp., 361 U.S. 459, 468-71 (1960), in which the Supreme Court ruled that an employer cannot set off damages caused by union breaches of the collective bargaining agreement against payments due pension fund trustees. The issue in Benedict essentially was one of contractual interpretation; the 
consideration to the employer in exchange for the hot cargo agreement, voiding the agreement might give a windfall to the employer; the court therefore simply enforced the contract. ${ }^{88}$

The court's concern for union pension fund trustees hardly is justified in the context of section $8(\mathrm{e})$. If the employer had raised the hot cargo issue before the Board, the pension fund provision would have enjoyed no special immunity from the prohibition in section $8(e) .{ }^{88}$ The fortuity of a judicial forum should not change the result in cases like these.

Moreover, section $8(\mathrm{e})$ is not designed to penalize unions for misconduct, but to protect neutral employers from illegal secondary boycott activities. ${ }^{90}$ When enforced by the pension fund trustees, the hot cargo agreement imposes the same costs on employers as when the union enforces it. If third party beneficiaries could enforce hot cargo agreements, unions would be able to impose those costs on employers indirectly, even though they may not do so directly.

Equitable considerations actually cut in favor of judicial resolution of hot cargo issues. It is a basic legal principle that courts

Court had to decide whether union compliance with the agreement was a condition precedent to the pension fund payments. Id. at 465 . Noting the devastating impact that a contrary rule would have on the viability of the welfare fund, the Court adopted a rule of contractual interpretation: "the parties to a collective bargaining agreement must express their meaning in unequivocal words before they can be said to have agreed that the union's breaches of its promises should give rise to a defense against the duty assumed by an employer to contribute to a union welfare fund ..." Id. at 471 .

In hot cargo cases under section $301(\mathrm{a})$, the court is not asked to interpret an admittedly valid term of a collective bargaining agreement; it must decide whether the pension fund obligation was illegal and unenforceable from its inception. See Huge v. Long's Hauling Co., 590 F.2d 457, 467-69 (3d Cir. 1978) (Rosenn, J., dissenting), cert. denied, 442 U.S. 915 (1979). At most, Benedict stands for the principle that when two interpretations of a clause are equally plausible, the court should adopt the one that will most protect the pension fund trustees; the case should not be interpreted to confer immunity from section 8(e) on pension fund trustees.

${ }^{88} 642$ F.2d at 1312-13. The union had performed fully its obligations under the contract, and only the employer's obligations under the alleged hot cargo agreement remained executory. The court distinguished this situation from one in which both union and employer obligations remain executory. Id. at $1318 \mathrm{n} .13$. The result in Mullins also reflects the general policy "of preventing people from getting other people's property for nothing when they purport to be buying it." Continental Wall Paper Co. v. Louis Voight \& Sons Co., 212 U.S. 227, 271 (1909) (Holmes, J., dissenting).

so Even the Mullins court conceded that the employer could bring his hot cargo allegation before the Board and, if he had a meritorious claim, that the Board could void the pension provision. 642 F.2d at 1314-15.

${ }^{\text {so }}$ See text and notes at notes $26-41,67-77$ supra. 
should not become parties to illegal conduct ${ }^{91}$ nor enforce a contract made in violation of public policy. ${ }^{.2}$ The federal courts routinely follow these precepts in actions to enforce labor-management agreements under section $301(\mathrm{a}) ;^{93}$ it is difficult to ascertain why illegal hot cargo agreements deserve greater judicial deference.

If the courts refuse to decide hot cargo issues, the employer bears an unfair burden; to resolve the claim of illegality, he must go to the Board.94 A weak employer may wish to leave the hot

91 Ewert v. Bluejacket, 259 U.S. 129, 138 (1922); Waskey v. Hammer, 223 U.S. 85, 94-95 (1912). See also UAW Local 985 v. W.M. Chace Co., 262 F. Supp. 114, 117-18 (E.D. Mich. 1966) ("[N]o court will order a party to do something, if in order to comply with the court's directive he must commit a crime. This is so despite any protestations that the party contracted to do what it is said that he should be ordered to do.").

92 See Hurd v. Hodge, 334 U.S. 24, 34-35 (1948):

The power of the federal courts to enforce the terms of private agreements is at all times exercised subject to the restrictions and limitations of the public policy of the United States as manifested in the Constitution, treaties, federal statutes, and applicable legal precedents. Where the enforcement of private agreements would be violative of that policy, it is the obligation of courts to refrain from such exertions of judicial power.

Cf. Dewey v. Reynolds Metals Co., 300 F. Supp. 709, 713 (W.D. Mich. 1969) (in Title VII actions, 42 U.S.C. $\S \S 2000 \mathrm{e}-2000 \mathrm{e}-17$ (1976 \& Supp. II 1978), labor-management agreement that violates civil rights statute is void), rev'd on other grounds, 429 F.2d 324 (6th Cir. 1970), aff'd by an equally divided court, 402 U.S. 689 (1971); Puerto Rico Dist. Council of United Bhd. of Carpenters v. Ebanisteria Quintana, 56 L.R.R.M. 2391 (D.P.R. 1964) (arbitration award is void to the extent that it violates labor statute).

o3 Under Lincoln Mills the federal courts may apply these principles in construing federal labor contracts under section 301(a). See note 56 supra; Mullins v. Kaiser Steel Corp., 642 F.2d 1302, 1331 (D.C. Cir. 1980) (Wilkey, J., dissenting), cert. granted, 101 S. Ct. 2044 (1981) (No. 80-1345); Waggoner v. R. McGray, Inc., 607 F.2d 1229, 1236 (9th Cir. 1979) (Williams, J., dissenting). Cf. Botany Indus., Inc. v. New York Joint Bd., Amalgamated Clothing Workers, 375 F. Supp. 485, 490-93 (S.D.N.Y. 1974) (in deciding whether a court may review the legality of an arbitration award the court noted the considerations involved in refusing to enforce the illegal contract), vacated and dismissed as moot sub nom. Robb v. New York Joint Bd., Amalgamated Clothing Workers, 506 F.2d 1246 (2d Cir. 1974).

Kelly v. Kossuga, 358 U.S. 516 (1959), poses a potential exception to this judicial refusal to enforce an illegal contract. The Supreme Court in this nonlabor case denied an antitrust defense to a breach of contract claim because the antitrust violation was too remote from the remedy the plaintiff sought. Id. at 520-21. See also Connolly v. Union Sewer Pipe Co., 184 U.S. 540, 549 (1902). The Kelly exception does not apply to hot cargo cases under section $301(a)$, because in those cases the courts are asked to enforce the evil explicitly prohibited by section 8(e). E.g., Waggoner v. R. McGray, Inc., 607 F.2d 1229 (9th Cir. 1979) (delinquent obligations clause).

- Furthermore, the NLRB's General Counsel may refuse to issue an unfair labor practice complaint on the employer's allegations. This action is unreviewable. 29 U.S.C. $\&$ 153(d) (1976); see NLRB v. Sears, Roebuck \& Co., 421 U.S. 132, 138-39 (1975). See generally Rosenblum, A New Look at the General Counsel's Unreviewable Discretion Not to Issue a Complaint under the NLRA, 86 YALE L.J. 1349 (1977). A refusal by the General Counsel to issue a complaint effectively would deprive the employer of any opportunity to contest the hot cargo issue, even if the employer's claim is meritorious. This result indicates that the 
cargo claim in repose until the union brings an action to enforce the contract. ${ }^{95}$ Unless the courts decide hot cargo issues in section 301(a) actions, an employer with a meritorious hot cargo allegation must go to the expense and delay of litigating its position in two forums before obtaining complete relief from the onerous agreement.

\section{A Proposal For Integrating Board and Judicial Remedies}

The possibility of conflict between decisions by the Board and by the courts in the same case ${ }^{98}$ should not prevent concurrent jurisdiction over hot cargo issues that arise in section 301(a) cases. Conflict could be avoided if the courts stayed section 301(a) proceedings until hot cargo issues were decided by the Board. ${ }^{97}$ As a general rule, however, this approach presents several problems. The NLRB's General Counsel may refuse to initiate unfair labor practice proceedings. Because his action is unreviewable, he effectively can prevent the Board from determining the legality of the alleged hot cargo agreement. ${ }^{98}$ In addition, judicial reliance on the Board's unfair labor practice proceedings may delay a final judgment in the contract action for up to one year. ${ }^{98}$ This result would

courts should decide hot cargo issues when they arise in section 301(a) actions to maximize the enforcement of the hot cargo prohibition in section 8(e). Cf. Vaca v. Sipes, 386 U.S. 171, 182-83 (1967) (if the court refused jurisdiction the General Counsel might do the same, leaving the plaintiff without a forum).

95 If the employer raises the hot cargo issue by repudiating the agreement, the union may file an unfair labor practice charge with the Board under section 8(a)(5), 29 U.S.C. $\S 158(a)(5)$ (1976). A weak employer may prefer to wait until the union sues for enforcement of the contract under section 301(a).

so Such conflict could arise in two ways. The Board could find that an agreement violated section 8(e) and issue a cease and desist order under section 10(c) of the LMRA, 29 U.S.C. $\$ 160$ (c) (1976), at the same time that the district court issued an order enforcing the agreement. Alternatively, the Board could find that the employer violated section $8(a)(5)$ by repudiating a lawful contract and could issue a bargaining order under section 10 (c), while the court refused under section 301 (a) to enforce the same agreement. This inconsistency might be resolved when the losing party appealed the district court's decision or when the Board petitioned the court of appeals to enforce its order under section 10(e), 29 U.S.C. $\S 160(e)$ (1976).

The potential conflict resembles that in the Personal Products litigation between the court, see United Textile Workers v. Textile Workers, 258 F.2d 743 (7th Cir. 1958), and the Board, see Personal Prods. Corp., 122 N.L.R.B. 563 (1958). The case involved judicial enforcement of a no-raiding pact in the face of the Board's preference for barring enforcement of the agreement. See Meltzer (pt. 2), supra note 6, at 295-97, 300.

${ }^{97}$ See text and notes at notes 15-16 supra.

ss See note 94 supra.

99 In 1976 the median length of time between the filing of an unfair labor practice charge and final Board decision was 358 days. E. Miller, An Administrative Appraisal or 
undermine the policy underlying section 301(a) of enforcing contracts promptly, ${ }^{100}$ as well as the policy underlying section $8(e)$ of providing a prompt and effective remedy for victims of secondary union activity. ${ }^{101}$ Moreover, courts do not refer hot cargo issues to the Board in section 303 cases, in which the employer is strong enough to resist union demands for inclusion of the clause in the contract; ${ }^{102}$ there is, if anything, less justification for judicial referral to the Board in section 301(a) cases in which the employer is too weak to resist union pressures.

Although concurrent jurisdiction presents an inevitable risk of inconsistent decisions, ${ }^{103}$ that risk is small. In many hot cargo cases arising under section 301(a), the employer may have no effective access to the processes of the Board. ${ }^{104}$ In some cases, the General Counsel already may have refused to issue an unfair labor practice charge in the same dispute. ${ }^{108}$ In other cases, the six-month limitation period for unfair labor practice charges ${ }^{106}$ effectively may prevent Board action on hot cargo allegations that are presented in court. ${ }^{107}$

When the same case is presented to both forums, there is no

the NLRB 142 (1977). See also B. Meltzer, Labor Law: Cases, Materials, and Problems 98-99 (2d ed. 1977).

100 See text and notes at notes 52-56 supra.

101 See text and notes at notes 30-41, 67-77 supra.

102 See text and notes at notes 71-77 supra.

${ }^{103}$ See text and note at note 72 supra.

${ }^{104}$ In several cases the Supreme Court has been more willing to permit a judicial remedy when there is no practical opportunity to obtain a Board characterization of the conduct involved. See Sears, Roebuck \& Co. v. San Diego County Dist. Council of Carpenters, 436 U.S. 180, 201-03 (1978) (employer could not raise issue to the Board except by forcibly provoking union unfair labor practice complaint); Vaca v. Sipes, 386 U.S. 171, 182-88 (1967) (Court concerned that Board processes might be closed to employee). See also Amalgamated Ass'n of St. Employees v. Lockridge, 403 U.S. 274, 326 (1971) (White, J., dissenting) ("For activity that is arguably protected, there is no provision for an authoritative decision by the Board in the first instance; yet the Garmon rule blindly pre-empts other tribunals.").

${ }^{105}$ See note 94 supra.

${ }^{108}$ LMRA § 10(b), 29 U.S.C. \$ 160(b) (1976).

107 In several hot cargo cases brought under section $301(\mathrm{a})$, the union pension fund trustees have argued that the six-month limitations period of section $10(\mathrm{~b})$ applies to hot cargo issues in section 301(a) actions as well as to hot cargo issues in NLRB proceedings. See Huge v. Long's Hauling Co., 590 F.2d 457, 469-70 \& nn. 4-5 (1978) (Rosenn, J., dissenting), cert. denied, 442 U.S. 18 (1979). This view is flawed for two reasons. First, the language of the statute only bars unfair labor practice proceedings before the Board. Moreover, section 8(e)'s policy of preventing the enforcement of hot cargo agreements requires that a judicial remedy be available for as long as any action to enforce the agreement might be filed. 
requirement that either the Board ${ }^{108}$ or the court ${ }^{100}$ adopt the other's concurrent or subsequent characterization of the hot cargo agreement; however, in the interest of comity, each forum should avoid making unnecessary characterizations of the hot cargo agreement. For example, the Second Circuit has deferred to the Board when expedited section $8(e)$ proceedings were under way and the Board had petitioned the court for a stay of the section 301(a) suit. ${ }^{110}$

When there has been a prior decision by the NLRB, the courts must defer to it if the Board's proceedings satisfy the requirements of res judicata or collateral estoppel. ${ }^{111}$ At the same time, the Board need not defer to prior judicial decisions; ${ }^{112}$ for the sake of

${ }^{108}$ See section 10(a) of the LMRA, which states in part:

The Board is empowered, as hereinafter provided, to prevent any person from engaging in an unfair labor practice . . a affecting commerce. This power shall not be affected by any other means of adjustment or prevention that have been or may be established by agreement, law, or otherwise.

29 U.S.C. $\S 160$ (a) (1976) (emphasis added). Cf. International Harvester Co., 138 N.L.R.B. 923, 925-26 (Board policy of deferring to arbitrators' awards on unfair labor practice issues does not deprive the Board of unfair labor practice jurisdiction in such cases), enforced sub nom. Ramsey v. NLRB, 327 F.2d 784 (7th Cir.), cert. denied, 377 U.S. 1008 (1964); NLRB v. Thayer Co., 213 F.2d 748 (1st Cir.) (state injunction not res judicata in subsequent NLRB action), cert. denied, 348 U.S. 883 (1954).

${ }^{108}$ Cf. United Brick \& Clay Workers v. Deena Artware, Inc., 198 F.2d 637, 642-43 (6th Cir.) (refusing in section 308 action to defer to concurrent NLRB decision in the same case), cert. denied, 344 U.S. 897 (1952). For cases involving judicial deference to NLRB decisions on representational and work assignment disputes that conflict with prior arbitration awards, see, e.g., Carey v. Westinghouse Elec. Corp., 375 U.S. 261, 272 (1964) (dictum noting that a subsequent NLRB ruling on work assignment dispute takes precedence over a contrary arbitrator's award); General Warehousemen \& Helpers Local 767 v. Standard Brands, Inc., $579 \mathrm{~F} .2 \mathrm{~d} 1282$ (5th Cir. 1978) (en banc) (refusing to enforce arbitration award inconsistent with Board's later representation award), cert. dismissed, 443 U.S. 913 (1979); UAW v. Rockwell Int'l Corp., 619 F.2d 580, 584-85 (6th Cir. 1980) (arbitrator's damage award unenforceable because of conflict with later NLRB decision in jurisdictional dispute); Local 7210, Oil Workers v. Union Tank Car Co., 475 F.2d 194 (7th Cir. 1973) (same as Rockwell), cert. denied, 414 U.S. 875 (1973). These cases are inapposite in the context of hot cargo cases under section 301(a) because they involve deference to the Board on issues that the Board is peculiarly competent to resolve. See Meltzer (pt. 2), supra note 6, at 292-95.

${ }^{110}$ National Maritime Union v. Commerce Tankers Corp., 457 F.2d 1127, 1138 (2d Cir. 1972).

11 Courts generally treat NLRB final judgments as being res judicata and as collaterally estopping issues in section 303 damage actions. See International Wire Co. v. Local 138, IBEW, 475 F.2d 1078 (6th Cir.), cert. denied, 414 U.S. 867 (1973); Paramount Transp. Sys. v. Teamsters Local 150, 436 F.2d 1064 (9th Cir. 1971); Painters Dist. Council v. Edgewood Constr. Co., 416 F.2d 1081 (5th Cir. 1969). But see Old Dutch Farms, Inc. v. Milk Drivers Local 584, 359 F.2d 598 (2d Cir.), cert. denied, 385 U.S. 832 (1966). The same rule presumably should apply in hot cargo cases brought under section $301(\mathrm{a})$.

112 See note 108 supra. 
mutual respect and cooperation, however, it should use its discretion to defer to previous judicial resolutions of hot cargo issues unless it finds them patently repugnant to the policies of the LMRA. ${ }^{113}$ What is most needed in hot cargo cases is for both the court and the Board to be sensitive to the demands of comity. ${ }^{114}$ Exercising their powers with discretion, the Board and the courts can minimize the risk of inconsistent decisions.

\section{Conclusion}

A careful examination of the language and legislative history of section 8(e) suggests that Congress intended federal courts to decide hot cargo issues arising in section 301(a) actions. In addition, the section 303 and fair representation exceptions to the NLRB's primary jurisdiction support a similar exception for hot cargo issues arising under section 301(a). The exception should apply regardless of whether the breach of contract action is brought by the union or by a pension fund trustee who is a third party beneficiary under the agreement. Conflict between the courts and the Board can be avoided if both forums use discretion in the exercise of their jurisdictional powers.

Richard B. Kapnick

113 Cf. Virginia-Carolina Freight Lines, Inc., 155 N.L.R.B. 447, 451 n.6 (1965) (Board will not defer to arbitration awards when the award is repugnant to the policies of the LMRA); Spielberg Mfg. Co., 112 N.L.R.B. 1080, 1081-82 (1955) (same). See also R. GoRMan, supra note $78, \S \S 31-2$ to -3 .

" Cf. Meltzer (pt.2), supra note 6, at 300 ("The difficulties and uncertainties surrounding Board and judicial power with respect to no-raiding pacts made it particularly desirable . . . for both tribunals to be sensitive to the demands of comity."). 